\title{
Mating system and fine-scale spatial genetic structure of Solanum lycocarpum St.Hil. (Solanaceae) in the Brazilian Cerrado
}

\author{
Karina Martins ${ }^{1,4, *}$, Lázaro José Chaves², Gláucia Salles Cortopassi Buso ${ }^{3}$ \& Paulo \\ Yoshio Kageyama ${ }^{1}$ \\ ${ }^{1}$ Departamento de Ciências Florestais, Laboratório de Reproducão e Genética de Espécies Arbóreas, \\ ESALQ-USP. Av. Pádua Dias, 11 CP 09, 13418-900, Piracicaba, SP, Brazil; ${ }^{2}$ Escola de Agronomia, Uni- \\ versidade Federal de Goiás, Setor de Melhoramento Vegetal. Rod. Goiânia - Nova Veneza km 0, Campus \\ Samambaia CP 131, 74001970, Goiânia, GO, Brazil; ${ }^{3}$ Parque Estação Biológica, Laboratório de Genética, \\ Embrapa - Recursos Genéticos e Biotecnologia, CP 02372, 70770-900, Brasília, DF, Brazil; ${ }^{4}$ Centro de \\ Pesquisa Agroflorestal do Acre-CPAFAC, BR 364, Km14, Caixa Postal 321, CEP 69901-108, Rio Branco, \\ Acre, Brazil (*Corresponding author: Phone: +55-68-32123251; Fax: +55-68-3212-3284; E-mail: \\ karimartins@yahoo.com)
}

Received 30 September 2005; accepted 13 February 2006

Key words: Cerrado, coancestry, cpSSR, ex situ conservation, mating system, Solanum lycocarpum

\begin{abstract}
Restricted gene dispersion - resulting from both self-pollination and limited capability of pollen migration, as well as seed dispersion at short distances - has been considered the main reason for spatial genetic structuring in plant populations. This study evaluated the intrapopulation genetic structure and the mating system in four populations of Solanum lycocarpum, a woody bush occurring in Brazilian Cerrado vegetation. Two hundred and twenty-four individuals were genotyped through five nuclear SSR loci (30 alleles) and six cpSSR loci ( 82 haplotypes). The study evidenced that the species mates predominantly by outcrossings $\left(\hat{t}_{\mathrm{m}} \sim 1.00\right)$, that biparental inbreeding is not common, and that there are almost 10 trees participating as pollen donors per mother-tree. The populations were formed by many mother lineages, indicating efficient seed dispersion by the fauna and the occurrence of multiple foundation events. Spatial genetic structure was observed in three populations (average $\mathrm{Sp}=0.0184 \pm 0.0030$ ) and it resulted from both restricted seed dispersion and from vegetative reproduction. During the collection of seeds for ex situ conservation, seeds must be gathered from 150 to 200 mother trees, so that the effective size of 500 individuals is retained. The sampling must comprise the biggest possible number of populations in a wide area to enable the maintenance of the biggest possible haplotypic diversity.
\end{abstract}

\section{Introduction}

Spatial genetic structure has mainly been associated with the features of species' mating system (Loveless and Hamrick 1984; Vekemans and Hardy 2004). These characteristics result in restricted gene dispersion as a consequence of both selfing and limited capability of pollen migration as well as short distance seed dispersion (Levin 1981; Loveless and Hamrick 1984). The distribution of pollen movement is usually leptokurtic, with the highest amount of pollen being deposited a few meters away from the source (Slatkin 1985). In most species, pollen is rarely transported further than 1000 m (Loveless and Hamrick 1984). However, seeds tend to be distributed near the mothertree and are seldom carried further than $200 \mathrm{~m}$ (Levin 1981; Howe and Smallwood 1982). In generalist species whose seeds are dispersed by a diversity of animals with different foraging habits and walking capabilities, the seed dispersion pattern and its contribution to the total gene flow 
vary according to the study spatial scale. At the microspatial scale (intrapopulation) plant regeneration near the mother-tree may generate relatedness structure between near individuals. When pollen dispersion is restricted, the spatial genetic structure may affect the outcrossing rate (Wright 1943). The occurrence of vegetative reproduction through roots and rhizomes may also cause spatial genetic structure. This process has already been detected in other species of the savanna-like vegetation of the Cerrado biome in Brazil (Rizzini and Heringer 1962) and it can be regarded as a regeneration strategy after the occurrence of fire, a common phenomenon in this biome (Hoffmann 1998).

The interest in studying genetic structuring in populations of plant species of the Cerrado biome is recent, as most of the works have been published in the present decade. However, the vast majority of the studies have focused on interpopulation genetic diversity, as illustrated in the following studies: Collevatti et al. (2001a, b, 2003), about Caryocar brasiliense; Telles et al. (2001a, b) and Zucchi et al. (2003), about Eugenia dysenterica; Telles et al. (2003), about Annona crassiflora; Lacerda et al. (2001), about Plathymenia reticula$t a$. Enquiries about the occurrence of vegetative reproduction and microspatial genetic structure in species of the Cerrado biome have not been published yet.

Knowledge of the spatial structure is important for defining sampling strategies in natural populations (Epperson 1990). It is beneficial both for collection of seeds for ex situ conservation in starting breeding programs, and for guiding in situ conservation strategies. The study of the species' mating system, as well as the quantification of gene flow mediated by pollen and seeds, are necessary for understanding the main ecologic mechanisms that cause spatial genotype structuring in populations of plant species. Mating system and gene flow are important determinants of effective population size and the estimation of effective population size is of critical importance in conservation planning (Hall et al. 1996). The concomitant use of molecular markers with different modes of inheritance is a powerful tool for determining pollen and seed migration distances (McCauley 1995). This strategy enables us to verify if the spatial structuring is a result of restrictions in pollen flow or seed flow or both.
The species $S$. lycocarpum St. Hil. presents interesting mating characteristics for the study of spatial distribution of genetic variation. It is andromonoecious, with constant and high production of both hermaphrodite and functionally male flowers, which are pollinated by short-flight bees (Oliveira-Filho and Oliveira 1988). Various Cerrado mammals that carry out long-distance seed dispersion allow for colonization in new environments. As the fruits only ripen after falling to the ground (Lombardi and Motta-Junior 1993), many seeds germinate under the canopy of the tree or are dispersed at short distances by sauba ants (Courtenay 1994). The species presents efficient regeneration after a shallow cut to the trunk (personal observation), hinting that it can produce vegetative reproduction. The aim of this study was to evaluate fine-scale spatial genetic structure in populations of $S$. lycocarpum. As the occurrence of self-pollination limits gene dispersion (especially in the cases of biparental inherited markers) and affects genotype spatial distribution in a way that is similar to the outcrossing between near individuals (Wright 1943), S. lycocarpum mating system was also studied.

\section{Methods}

The species Solanum lycocarpum

Solanum lycocarpum St. Hil (Solanaceae), popularly known as "lobeira" (wolf's fruit), consists of a fast-growing woody bush up to $2 \mathrm{~m}$ tall. The species is regarded as an opportunist and colonizer of anthropogenic areas such as roadsides, open lands and pastures (Oliveira-Filho and Oliveira 1988; Courtenay 1994). Its distribution area encompasses the Cerrado vegetation in Central Brazil (Lorenzi 2000). Its floral features are in accordance with both buzz pollination (Pijl 1972) and vibratile pollination (Buchmann 1983), in which the movement of the bee in the flower raises a cloud of pollen. Large Xylocopa bees are considered to be its most frequent and efficient pollinators (Oliveira-Filho and Oliveira 1988). The species flowers all year round, mainly from May to July (Lorenzi 2000). S. lycocarpum is an andromonoecious species, as the same tree holds different types of flowers: hermaphrodite and functionally male (with an atrophic stigma). 
Its fruit is big, round and greenish with a diameter ranging from 8 to $15 \mathrm{~cm}$ and weighing from 200 to $900 \mathrm{~g}$. Its pulp is yellow, holding about 300-800 small black seeds. The complete maturation and the exhalation of its characteristic aroma occur after the fruit falls (Lombardi and Motta Junior 1993). Although the fruits grow all year round, their availability varies seasonally, that is, the species fruits more intensively in the rainy season (Courtenay 1994; Motta-Junior and Martins 2002). Wild animals consume its fruits, especially maned wolves (Motta Junior et al. 1996; Rodrigues 2002), bats (Lorenzi 1998; Rodrigues 2002), tapirs, sauba ants (Courtenay 1994; Pinto 1998) and bush dogs (Rodrigues 2002). Studies about the dispersion of $S$. lycocarpum seeds show that the maned wolf is the main disperser of the species (Rodrigues 2002). This fruit is highly and constantly consumed by the maned wolf all year round (non-seasonal) (Courtenay 1994; Motta Junior et al. 1996; Motta-Junior and Martins 2002; Rodrigues 2002), which suggests that the maned wolf looks for it actively during the periods when it is scarcer (in the dry season). The animal does not damage the consumed seeds and it defecates in places where the plant usually grows, such as roadsides (Motta-Junior and Martins 2002).

The fruit pulp is employed in the production of a phytomedicine, the "wolf"s fruit-powder" ("polvilho-de-lobeira") which is sold in the form of capsules and widely used for controlling diabetes, obesity, and cholesterol levels (Dall'Agnol and von Poser 2000). The leaves are used for treatment of epilepsy, spasms, abdominal and renal pain (Cruz 1982). S. lycocarpum is a species with a wide potential for being planted in restoration plans. It presents a high rate of germination, the seeds germinate in full sunlight, the plant grows quickly and adapts well to situations of scarce water (ChavesFilho and Stacciarini-Seraphin 2001; Elias et al. 2003). In addition, it produces meaty fruits that attract fauna to its vegetated areas.

\section{Sampling}

Two hundred and twenty-four adult individuals of $S$. lycocarpum were sampled in four natural populations in the Southeast of Goiás State in Central Brazil (Figure 1). Individuals were randomly sampled in population B and a census was carried out in populations $\mathrm{A}, \mathrm{C}$ and $\mathrm{D}$. The spatial loca- tion of the trees was determined by the use of GPS equipment (e-trex, Garmin ${ }^{\circledR}$ ). Twelve progenies of open pollination were obtained for the study of the mating system in two populations (B and C). The number of individuals per progeny was variable.

\section{Laboratorial procedure}

The extraction of DNA was carried out following CTAB protocol as described by Doyle and Doyle (1990). The DNA extraction was optimized after the removal of the hairs that cover the surface of the leaves with a blade. The DNA samples were resuspended and diluted in MiliQ water at $5 \mathrm{ng} / \mu \mathrm{l}$. The individuals were genotyped with six nuclear microsatellite loci developed for Capsicum spp. (Buso et al. 2000) (Table 1) and six chloroplast microsatellite loci developed for dicotyledonous angiosperms by Weising and Gardner (1999) (Table 2).

The cocktail $(13 \mu \mathrm{l})$ for the production of the polymerase chain reaction (PCR) was composed of $15.0 \mathrm{ng}$ of genomic DNA, $250 \mu \mathrm{M}$ of dNTPs, $0.5 \mu \mathrm{M}$ of $\mathrm{MgCl}_{2}$, buffer PCR $1 \times(10 \mathrm{mM}$ of Tris- $\mathrm{HCl}, 50 \mathrm{mM}$ of $\mathrm{KCl}, 1.5 \mathrm{mM}$ of $\mathrm{MgCl}_{2}$, $\mathrm{pH} 8.3), 2.5 \mu \mathrm{g} / \mathrm{ml}$ of BSA, $0.2 \mu \mathrm{M}$ of each primer and $1 \mathrm{U}$ of Taq DNA polymerase (Phoneutria). The PCRs were produced in a MJ Research PTC-100 thermal-cycler, with the use of the following protocol: $96^{\circ} \mathrm{C}$ for $2 \mathrm{~min} ; 30$ cycles of $94{ }^{\circ} \mathrm{C}$ for $1 \mathrm{~min}$, specific hybridizing temperature of each pair of primers for $1 \mathrm{~min}, 72^{\circ} \mathrm{C}$ for $1 \mathrm{~min}$ and finishing with $72^{\circ} \mathrm{C}$ for $7 \mathrm{~min}$. After amplification, fragments of DNA were separated in a $4 \%$ polyacrylamide denaturing gel by electrophoresis for $1 \mathrm{~h}$ in a $1 \times \mathrm{TBE}$ buffer in a vertical tub. Bands were observed after being colored with silver nitrate, following Creste et al. (2001) protocol. The size of alleles was determined by comparison with a pattern molecular weight marker (10-bp ladder, Invitrogen ${ }^{\circledR}$ ). Amplified fragments of different sizes were considered different alleles.

\section{Data analysis}

\section{Genetic diversity}

Intrapopulation genetic diversity was analyzed by the observed heterozygosity $\left(\hat{H}_{\mathrm{o}}\right)$, gene diversity 


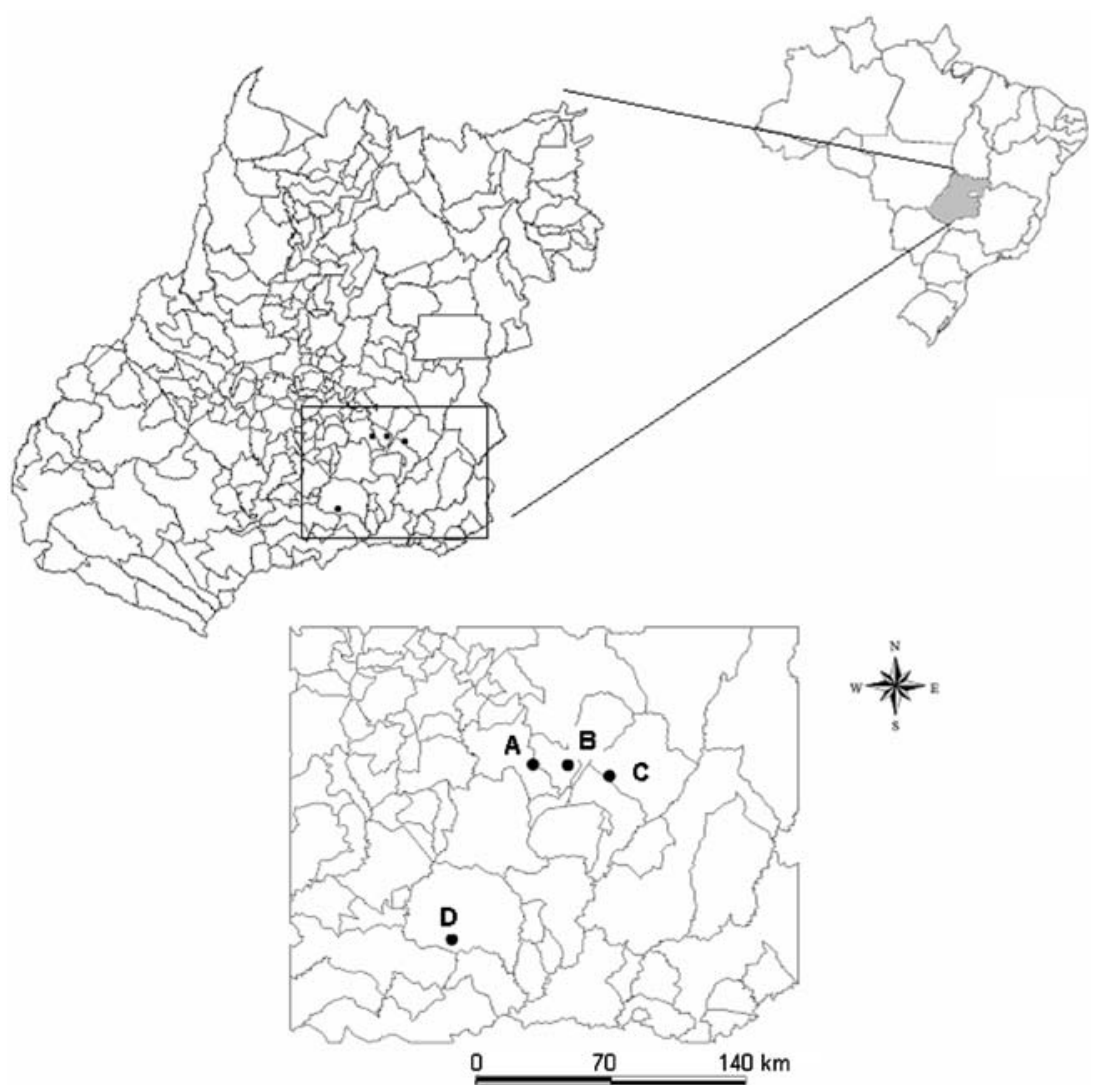

Figure 1. Localization of the four areas where Solanum lycocarpum were sampled in Goiás state, in Brazil.

Table 1. Characterization of nuclear SSR loci

\begin{tabular}{|c|c|c|c|c|}
\hline Loci & $T_{\mathrm{m}}\left({ }^{\circ} \mathrm{C}\right)$ & Primer sequences $\left(5^{\prime}-3^{\prime}\right)$ & Motif $^{a}$ & Allele range (bp) \\
\hline \multirow[t]{2}{*}{ CA23 } & 56 & ggCTCCTAggTATgCACCAg & $(\mathrm{TC})_{31}$ & $100-102$ \\
\hline & & AATgTgATgCACAgTgCACC & & \\
\hline \multirow[t]{2}{*}{ CA53 } & 56 & CgACCTTCAggACAgATCAT & $(\mathrm{TC})_{25}$ & 190-194 \\
\hline & & CTggTAACCTAgAAAggCAg & & \\
\hline \multirow[t]{2}{*}{ CA88 } & 54 & AATggATgTTCCCTTgCTTT & $(\mathrm{AG})_{22}$ & 140 \\
\hline & & CAACTgATCAACCATTCCgT & & \\
\hline \multirow[t]{2}{*}{ CA144 } & 54 & TAgAAACACAAAATgTCCCC & $(\mathrm{GT})_{5}$ & $86-88$ \\
\hline & & CCATTgACAAggACAATTCT & $(\mathrm{GA})_{21}$ & \\
\hline \multirow[t]{2}{*}{ CA158 } & 56 & CATgCACgTACAACCTgTTT & $(\mathrm{GA})_{32}$ & $198-250$ \\
\hline & & TAgTTCCCTTgCTgCAgTAA & & \\
\hline \multirow[t]{2}{*}{ CA161 } & 54 & CAggTACgTgCTgCTATCAA & $(\mathrm{GA})_{27}$ & $174-186$ \\
\hline & & TTggTAAgAAggCCTggTAA & & \\
\hline
\end{tabular}

${ }^{\mathrm{a}}$ Motifs in Capsicum spp.

$\left(\hat{H}_{\mathrm{e}}\right)$, average number of alleles per locus $(\hat{A})$, effective number of alleles per locus $\left(\hat{A}_{\mathrm{e}}\right)$ and fixation index $(\hat{f})$, estimations obtained from GDA software (Lewis and Zaykin 2001). The identification of genotyping errors in the data set, due to the existence of null alleles and scoring errors was verified by the use of program Micro-Checker Version 2.2.3 (Oosterhout et al. 2004).

As the chloroplast genome polymorphisms are inherited without recombination, each of the allele combinations in the six microsatellite loci was considered a haplotype. In its turn, each haplotype 
Table 2. Characterization of cpSSR loci

\begin{tabular}{lllll}
\hline Loci & $T_{\mathrm{m}}\left({ }^{\circ} \mathrm{C}\right)$ & Motif $^{\mathrm{a}}$ & Alleles & Allele range (bp) \\
\hline ccmp02 & 58 & $(\mathrm{~A})_{11}$ & 5 & $184-192$ \\
ccmp03 & 54 & $(\mathrm{~T})_{11}$ & 8 & $108-122$ \\
ccmp05 & 54 & $(\mathrm{C})_{7}(\mathrm{~T})_{10}(\mathrm{~T})_{5} \mathrm{C}(\mathrm{A})_{11}$ & $122-128$ \\
ccmp07 & 56 & $(\mathrm{~A})_{13}$ & 4 & $148-152$ \\
ccmp09 & 50 & $(\mathrm{~T})_{11}$ & 3 & $102-104$ \\
ccmp10 & 56 & $(\mathrm{~T})_{14}$ & 3 & $108-112$ \\
\hline
\end{tabular}

${ }^{a}$ Motif observed in Nicotiana tabacum (Weising and Gardner 1999).

was analyzed as a different allele belonging to an only haploid locus. The number of haplotypes $\left(\hat{n}_{\mathrm{h}}\right)$, the amount of private haplotypes per population $\left(\hat{n}_{\mathrm{p}}\right)$, and the rate of private alleles $\left(\hat{n}_{\mathrm{p}} / \hat{n}_{\mathrm{h}}\right)$ were quantified. The frequencies of haplotypes in each population were used to estimate the effective number of haplotypes $\left(n_{\mathrm{e}}=1 / \sum p_{i}^{2}\right)$ and the haplotypic diversity $\left(h=n_{\mathrm{k}} / n_{\mathrm{k}}-1\left(1-\sum_{i}^{n} p_{i}^{2}\right)\right.$, where $n_{\mathrm{k}}$ is the number of individuals in population $\mathrm{k}, p_{i}$ is the frequency of the $i$-th haplotype.

\section{Spatial genetic structure}

Spatial genetic structure was characterized upon the analysis of kinship coefficients $\left(\hat{F}_{i j}\right)$ between all pairs of individuals of the population, which were estimated as in Loiselle et al. (1995). Average pairwise $\hat{F}_{i j}$ estimates were plotted against the logarithm of the pairwise spatial distances. Under isolation by distance in a two dimensional space, kinship is expected to decrease approximately linearly with the logarithm of the spatial distance (Rousset 1997; Hardy and Vekemans 1999). The regression slope $\left(\hat{b}_{F}\right)$ was used to quantify the extent of spatial genetic structure, using the Sp statistic described in Vekemans and Hardy (2004). The Sp statistic was obtained by the ratio $-\hat{b}_{F} /\left(1-\hat{F}_{(1)}\right)$, where $\hat{F}_{(1)}$ is the average $\hat{F}_{i j}$ between adjacent individuals (in the first distance interval). The significance of the $\hat{b}_{F}$ was tested by 10,000 permutations of individuals among spatial positions. All the computations were carried out with the use of the computer program SPAGeDi version 1.2 (Hardy and Vekemans 2002; http:// www.ulb.ac.be/sciences/lagev).

\section{Detection of clones}

In each population, we searched for individuals sharing nuclear and chloroplast multilocus genotypes. Then, it was verified if each specific group of identical multilocus genotypes were likely to be clones. The probability of observing at least $n$ identical multilocus genotypes in a specific sample from a population with random mating, $P_{\mathrm{SEX}}{ }^{-}$ value, were estimated as in Stenberg et al. (2003). The $P_{\text {SEX }}$ as well as the simulating critical values $(10,000$ simulations and significance level of 0.05$)$ was estimated by the use of the MLGSim computer program (Stenberg et al. 2003). A significantly low $P_{\text {SEX }}$-value indicates that a multilocus genotype observed more than once is not likely the result of random sexual reproduction (and hence assumed to be clonally produced). Only nuclear multilocus genotypes were used because the formula and the program only work with diploid individuals.

\section{Mating system}

The mating system was studied using genotypic frequencies as a basis and applying the mixed mating model of Ritland and Jain (1981). Program MLTR V. 2.4 (Ritland 2002) was employed so that we could obtain estimations of: (1) multilocus population outcrossing rate $\left(\hat{t}_{\mathrm{m}}\right)$ through Expectation-Maximization; (2) the single-locus population outcrossing rate $\left(\hat{t}_{\mathrm{s}}\right)$; (3) the biparental inbreeding or outcrossing between relatives $\left(\hat{t}_{\mathrm{m}}-\hat{t}_{\mathrm{s}}\right)$; (4) paternity correlation $\left(\hat{r}_{\mathrm{p}}\right)$ and (5) self-pollination correlation $\left(\hat{r}_{\mathrm{s}}\right)$. The size of the neighborhood, or the number of pollen donors, was estimated by $1 / \hat{r}_{\mathrm{p}}$. The standard errors were obtained by means of 500 bootstraps of families.

The fixation index for adults $(\hat{f})$ and progenies $\left(\hat{F}_{\mathrm{p}}\right)$ and their respective confidence intervals were obtained through 10,000 bootstraps by the use of program GDA (Lewis and Zaykin 2001).

The relatedness correlation coefficient $\left(r_{x y}\right)$ between plants within the progenies was estimated according to Ritland (1989):

$$
\hat{r}_{x y}=0.25\left(1+\hat{F}_{\mathrm{m}}\right)\left[4 \hat{s}+\left(\hat{t}_{\mathrm{m}}^{2}+\hat{s} \hat{t}_{\mathrm{m}} \hat{r}_{\mathrm{s}}\right)\left(1+\hat{r}_{\mathrm{p}}\right)\right]
$$


Where $\hat{F}_{\mathrm{m}}$ is the inbreeding coefficient of the parental generation, $\hat{s}$ is the selfing rate $\left(1-\hat{t}_{\mathrm{m}}\right)$, and the other parameters were defined previously.

In diploid species, in the absence of inbreeding, the relatedness coefficient $\left(\hat{r}_{x y}\right)$ is double the coancestry coefficient $(\hat{\theta})$, that is, $\hat{\theta}=\hat{r}_{x y} / 2$. As demonstrated by Cockerham (1969), from the coancestry coefficient it is possible to estimate the variance effective size $\left(\hat{N}_{\mathrm{e}(v)}\right)$ of a progeny

$$
\hat{N}_{\mathrm{e}(v)}=\frac{0.5}{\hat{\theta}\left(\frac{n-1}{n}\right)+\frac{1+\hat{F}}{2 n}}
$$

In which $n$ corresponds to the sample size (number of plants per progeny), and $\hat{F}$ is the progeny fixation index.

The maximum theoretical value of $N_{\mathrm{e}}(v)$ in an ideal population's simple progeny (infinite size, panmictic, without selection, mutation or migration) is approximately four. From the estimations of the variance effective size $\left(N_{\mathrm{e}}(v)\right)$, the number of necessary mother trees was estimated to keep the effective size $\left(N_{\mathrm{e}}(\mathrm{ref})\right)$ equal to 500 , this being the result of the division $N_{\mathrm{e}}(\mathrm{ref}) / N_{\mathrm{e}}(v)$, as presented by Sebbenn (2003).

\section{Results}

Individuals from the four natural populations were genotyped with six loci of nuclear microsatellites. Thirty alleles were detected. Polymorphism was very low in most of the loci, as is expected for microsatellite markers developed for a different genus (Capsicum), and only locus CA158 presented a high number of alleles (17). The dimension of gene diversity was quantified by a comparison between the estimated gene diversity $\left(\hat{H}_{\mathrm{e}}\right)$ and the maximum possible diversity in each locus according to the number of alleles $\left(h_{\max }=(\hat{A}-1) / \hat{A}\right)$. It was observed that loci CA23 and CA158 presented the highest gene diversity, once the data explains 98.8 and $89.7 \%$ of the total possible diversity (Table 3). Locus CA144 presented medium diversity estimations and for loci CA53 and CA161 the rates of gene diversity were below $10 \%$. The low gene diversity is a result of the gene frequency heterogeneity in these loci, i.e., it is due to the occurrence of one highly frequent allele together with a few rare alleles, and the presence of monomorphic loci in some populations. For estimations of gene diversity, it was decided that locus CA88 was to be excluded, owing to it being monomorphic in all populations. The average estimations obtained were, therefore, calculated with data from five loci.

The estimations of the average number of alleles per locus $(\hat{A}=3.90 \pm 0.19)$ were low (Table 4). The effective number of alleles per locus $\left(\hat{A}_{\mathrm{e}}=2.32 \pm 0.11\right)$ was lower than the observed number of alleles. It was due to the uneven distribution of allele frequencies, as discussed previously. Despite the standard errors being large, a smaller number of alleles were observed in population D.

The gene diversity $\left(\hat{H}_{\mathrm{e}}=0.331 \pm 0.016\right)$ and the observed heterozygosity $\left(\hat{H}_{\mathrm{o}}=0.302 \pm 0.018\right)$ were lower than what is expected from microsatellite markers, but they were consistent with the number of alleles. Once again, in Population D these estimations were lower than the other populations. The estimations of observed heterozygosity $\left(\hat{H}_{\mathrm{o}}\right)$ were similar to gene diversity $\left(\hat{H}_{\mathrm{e}}\right)$ in almost all populations, which can be observed in the estimations of fixation indices.

Only population A presented a wide deviation in the proportions of Hardy-Weinberg Equilibrium $(\hat{f}=0.214)$. Confidence intervals of $\hat{f}$ were

Table 3. Genetic diversity parameters estimated with six nuclear SSR loci

\begin{tabular}{lcccc}
\hline Locus & $\hat{A}$ & $\hat{H}_{\mathrm{e}}$ & $h_{\max }$ & $\hat{H}_{\mathrm{e}} / h_{\max }(\%)$ \\
\hline CA23 & 2 & 0.494 & 0.500 & 98.8 \\
CA53 & 3 & 0.043 & 0.667 & 6.45 \\
CA88 & 1 & 0.000 & - & - \\
CA144 & 2 & 0.310 & 0.500 & 62.0 \\
CA158 & 17 & 0.847 & 0.940 & 89.7 \\
CA161 & 5 & 0.017 & 0.800 & 2.1 \\
\hline
\end{tabular}

$\hat{A}$, allele number; $\hat{H}_{\mathrm{e}}$, gene diversity; $h_{\max }$, maximum possible gene diversity; $\hat{H}_{\mathrm{e}} / h_{\max }$, proportion of the maximum possible gene diversity $(\%)$. 
Table 4. Population genetic diversity parameters estimated with six nuclear SSR loci

\begin{tabular}{llllllr}
\hline Population & $n$ & $\hat{A}$ & $\hat{A}_{\mathrm{e}}$ & $\hat{H}_{\mathrm{e}}$ & $\hat{H}_{\mathrm{o}}$ & $\hat{f}\left(\mathrm{CI}_{99 \%}\right)^{\mathrm{a}}$ \\
\hline A & 58 & $3.80(1.56)$ & $2.09(0.73)$ & $0.342(0.139)$ & $0.269(0.138)$ & $0.214(0.0002,0.814)$ \\
B & 60 & $4.20(1.71)$ & $2.35(0.87)$ & $0.348(0.144)$ & $0.350(0.138)$ & $-0.006(-0.067,0.052)$ \\
C & 60 & $4.20(2.45)$ & $2.62(1.18)$ & $0.353(0.161)$ & $0.313(0.138)$ & $0.077(-0.094,0.170)$ \\
D & 55.33 & $3.40(1.92)$ & $2.24(1.04)$ & $0.283(0.154)$ & $0.278(0.137)$ & $0.0016(-0.158,0.123)$ \\
Average & & $3.90(0.19)$ & $2.32(0.11)$ & $0.331(0.016)$ & $0.302(0.018)$ & \\
\hline
\end{tabular}

Sample size $(n)$, average and effective number of alleles per locus $\left(\hat{A}\right.$ and $\left.\hat{A}_{\mathrm{e}}\right)$, gene diversity $\left(\hat{H}_{\mathrm{e}}\right)$, observed heterozygosity $\left(\hat{H}_{\mathrm{o}}\right)$ and fixation index $(\hat{f})$ in four populations of $S$. lycocarpum. Standard errors are in parentheses ( ).

${ }^{a}(\mathrm{CI})$ confidence interval at $99 \%$, through 10,000 bootstraps over loci.

wide due to the high variation between loci. Locus CA158 showed deviations from HWE in all populations, presenting the largest values of $\hat{f}$ (data not shown). Null alleles were not verified in the data set. Only loci CA53 and CA144 in population $\mathrm{A}$ and locus CA158 in population $\mathrm{C}$ showed evidence for null alleles and scoring errors due to stuttering. As the loss of heterozygosity was not consistent only in the same loci in the different populations, we conclude that there is no sign of null alleles.

As opposed to the low diversity obtained by nuclear microsatellite markers, the gene diversity for chloroplast markers was very high with 82 haplotypes detected. The number of haplotypes $\left(\hat{n}_{\mathrm{h}}\right)$ and haplotypic diversity $(\hat{h})$ were high in all the populations (Table 5). This shows that they were founded by a great number of mother families, i.e., they were colonized by seeds from different mother trees.

As it was detected with nuclear markers, population $D$ presented the lowest number of haplotypes $\left(\hat{n}_{\mathrm{h}}=19\right)$ and the smallest haplotypic diversity $(\hat{h}=0.910)$, indicating that it was founded by a smaller number of mother lineages. In all the populations, the effective number of haplotypes $\left(\hat{n}_{\mathrm{e}}\right)$ was approximately half of the total number of haplotypes (Table 5). The heterogeneity of haplotype frequencies contributed to the low estimations of $\hat{n}_{\mathrm{e}}$. Many haplotypes occurred only once and therefore present a low frequency and only a few have a slightly higher frequency (Figure 2). About $55 \%$ of the haplotypes were sampled only once and $25 \%$ occurred twice, which is a sign that several haplotypes may not have been sampled in this study.

\section{Spatial genetic structure}

Global average regression slopes were significantly negative in populations $\mathrm{B}, \mathrm{C}$, and $\mathrm{D}: \hat{b}_{F} \pm \mathrm{SE}$ (jackknife over loci $)=-0.0141 \pm 0.0022 \quad(P<0.002$; $\left.r^{2}=0.0066\right), \hat{b}_{F} \pm \mathrm{SE}=-0.0154 \pm 0.0039(P<0.001$; $\left.r^{2}=0.0072\right), \hat{b}_{F} \pm \mathrm{SE}=-0.0215 \pm 0.0109(P=0.00 ;$ $\left.r^{2}=0.0182\right)$ in populations $\mathrm{B}, \mathrm{C}$ and $\mathrm{D}$, respectively. Sp statistics were $0.01466,0.01625$ and 0.02429 , in populations $\mathrm{B}, \mathrm{C}$ and $\mathrm{D}$, respectively, with an average of $0.0184 \pm 0.0030$.

\section{Detection of clones}

Based on nuclear and chloroplast genotypes similarities, 16 multilocus genotypes groups were

Table 5. Population genetic diversity parameters estimated with chloroplast DNA

\begin{tabular}{llllll}
\hline Population & $\hat{n}_{\mathrm{h}}$ & $\hat{n}_{\mathrm{e}}$ & $\hat{n}_{\mathrm{p}}$ & $\hat{n}_{\mathrm{p}} / \hat{n}_{\mathrm{h}}(\%)$ & $\hat{h}$ \\
\hline A & 35 & 17.75 & 13 & 37.1 & 0.972 \\
B & 31 & 15.72 & 11 & 35.5 & 0.973 \\
C & 27 & 13.99 & 11 & 40.7 & 0.932 \\
D & 19 & 9.94 & 13 & 68.4 & 0.910 \\
Average (standard error) & $28(3.41)$ & $14.35(1.66)$ & $12(0.58)$ & 42.86 & $0.947(0.015)$ \\
\hline
\end{tabular}

Number of haplotypes $\left(\hat{n}_{\mathrm{h}}\right)$, effective number of haplotypes $\left(\hat{n}_{\mathrm{e}}\right)$, number and proportion of private haplotypes $\left(\hat{n}_{\mathrm{p}}\right.$ and $\left.\hat{n}_{\mathrm{p}} / \hat{n}_{\mathrm{h}}\right)$ and haplotypic diversity $(\hat{h})$ in four populations of S. lycocarpum. Standard errors are in parentheses ( ). 

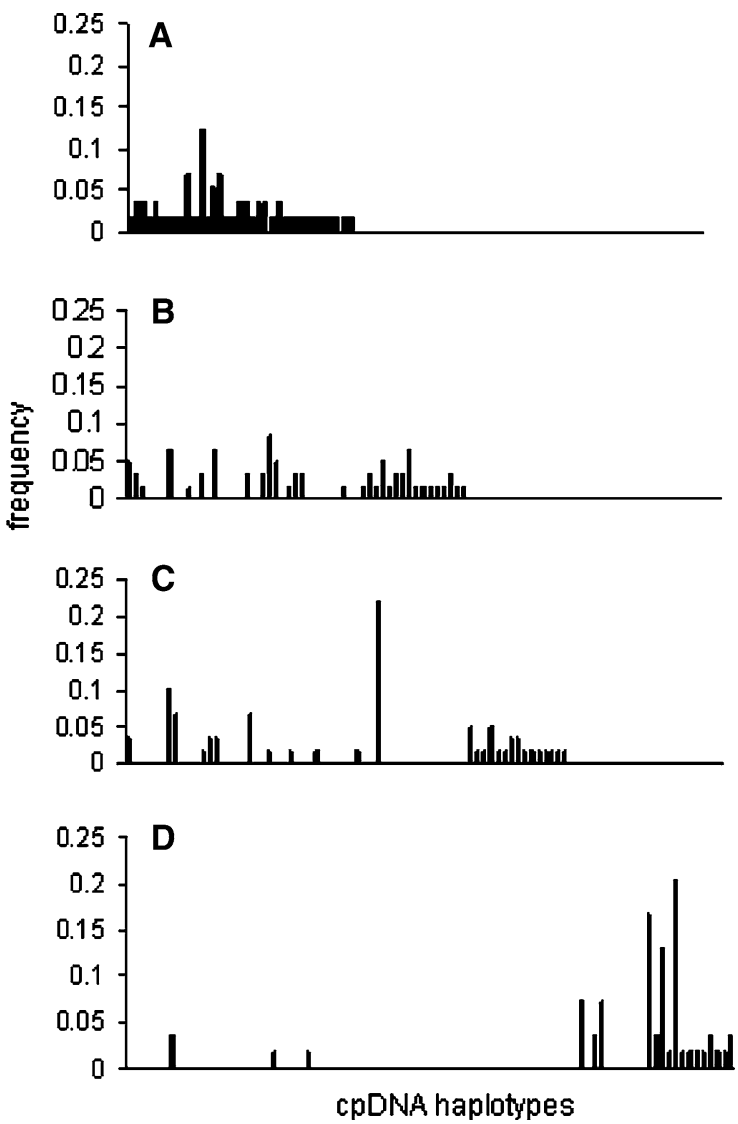

Figure 2. Frequency distribution of cpDNA haplotypes observed for four populations of Solanum lycocarpum.

detected. Seven groups were observed in population $\mathrm{D}$ and three groups were observed each population A, B and C. Seventy-five percent of the groups was composed only by two adjacent genotypes, but groups with three and four genotypes were also observed. Only two out of 16 groups sharing identical multilocus genotypes (in populations $\mathrm{B}$ and $\mathrm{D}$ ) were considered clones, as their $P_{\mathrm{SEX}}$-values were significant at the 0.05 level.
As the number of nuclear loci and alleles analyzed was small, it was not possible to state confidently that individuals considered identical in this study were clones.

\section{Mating system}

The estimations of multilocus outcrossing rate $\left(\hat{t}_{\mathrm{m}}\right)$ were approximately one in almost all the families (Table 6), indicating that $S$. lycocarpum mates preferably by outcrossing. Despite the variation between families, high standard errors were observed in those whose value of $\hat{t}_{\mathrm{m}}$ was smaller than 0.80 .

The estimations of average multilocus $\left(\hat{t}_{\mathrm{m}}\right)$ and singlelocus $\left(\hat{t}_{\mathrm{s}}\right)$ outcrossing rates did not differ from each other in both populations, which shows that biparental inbreeding $\left(\hat{t}_{\mathrm{m}}-\hat{t}_{\mathrm{s}}\right)$ is not common (Table 7). For population B, for instance, only $9.8 \%$ of progenies result from the same male parent $\left(\hat{r}_{\mathrm{p}}=0.098\right)$. With paternity correlations the average number of outcross parents was obtained. In the studied populations, this average was over 10 pollen-donor trees per progeny.

The rate of self-pollinations was also insignificant. Fixation indices in adults and in progenies were not statistically significant in both populations. Based on the relationship coefficient $\left(\hat{r}_{x y}\right)$ calculated for the progenies, we obtained the coancestry coefficient $(\hat{\theta})$. Coancestry estimations within the progenies presented values that were near the expected for half-sib progenies $(\hat{\theta}=0.125)$, in populations $\mathrm{B}(\hat{\theta}=0.137)$ and $\mathrm{C}$ $(\hat{\theta}=0.138)$. With the estimations of the variance effective size $\left(\hat{N}_{\mathrm{e}(v)}\right)$ from 3.01 to 3.48 for populations $\mathrm{B}$ and $\mathrm{C}$, we calculated the minimum number of mother trees to be considered in the seed collection for ex situ conservation. Aiming at the maintenance of the long-term genetic diversity, we must gather seeds from 166 and 144 mother trees

Table 6. Multilocus outcrossing rates each family and standard errors through 500 bootstraps within families obtained in populations $\mathrm{B}$ and $\mathrm{C}$

\begin{tabular}{llllll}
\hline Family & Progenies & $\hat{t}_{\mathrm{m}}$ & Family & Progenies & $\hat{t}_{\mathrm{m}}$ \\
\hline Fam B1 & 40 & $1.000(0.000)$ & Fam B9 & 18 & $0.897(0.109)$ \\
Fam B2 & 07 & $0.968(0.038)$ & Fam B10 & 06 & $0.996(0.005)$ \\
Fam B5 & 11 & $0.989(0.019)$ & Fam B12 & 25 & $0.772(0.184)$ \\
Fam B6 & 31 & $1.000(0.000)$ & Fam C1 & 29 & $0.970(0.045)$ \\
Fam B7 & 08 & $0.983(0.009)$ & Fam C3 & 28 & $0.840(0.097)$ \\
Fam B8 & 08 & $0.984(0.002)$ & Fam C5 & 07 & $1.000(0.000)$ \\
\hline
\end{tabular}


Table 7. Mating system estimations in two populations of S. lycocarpum

\begin{tabular}{llc}
\hline Populations & $\mathrm{B}$ & $\mathrm{C}$ \\
Families (progenies) & $09(154)$ & $03(64)$ \\
\hline$\hat{t}_{\mathrm{m}}$ & $1.000(0.003)$ & $0.956(0.026)$ \\
$\hat{t}_{\mathrm{s}}$ & $0.969(0.021)$ & $0.920(0.047)$ \\
$\hat{t}_{\mathrm{m}}-\hat{t}_{\mathrm{s}}$ & $0.031(0.020)$ & $0.036(0.022)$ \\
$\hat{r}_{\mathrm{p}}$ & $0.098(0.017)$ & $0.087(0.024)$ \\
$\hat{r}_{\mathrm{s}}$ & $0.107(0.001)$ & $0.054(0.005)$ \\
$1 / \hat{r}_{\mathrm{P}}$ & 10.20 & 11.49 \\
$\hat{F}$ (adults) & $-0.006[-0.067,0.052]$ & $0.077[-0.094,0.170]$ \\
$\hat{F}_{\mathrm{p}}$ (progenies) & $-0.036[-0.058,0.092]$ & $-0.062[-0.156,0.008]$ \\
\hline
\end{tabular}

Multilocus outcrossing rate $\left(\hat{t}_{\mathrm{m}}\right)$, single-locus outcrossing rate $\left(\hat{t}_{\mathrm{s}}\right)$, biparental inbreendig $\left(\hat{t}_{\mathrm{m}}-\hat{t}_{\mathrm{s}}\right)$, paternity correlation $\left(\hat{r}_{\mathrm{p}}\right)$, selfpollination correlation $\left(\hat{r}_{\mathrm{s}}\right)$, number of pollen donors per mother-tree $\left(1 / \hat{r}_{\mathrm{P}}\right)$, fixation index for adults $(\hat{f})$ and progenies $\left(\hat{F}_{\mathrm{p}}\right)$. Standard errors through 500 bootstraps over families are in parentheses (). Confidence interval at $99 \%$ through 10,000 bootstraps over loci is in brackets [ ].

from populations $\mathrm{B}$ and $\mathrm{C}$, respectively, in order to maintain the effective size of 500 .

\section{Discussion}

The polymorphism in nuclear loci was low, resulting in estimations of genetic diversity that were lower than expected for the type of molecular marker used. This was, probably, due to the fact that the microsatellite primers had been developed for Capsicum. The same observation was made in a study carried out with another fruit species of the Cerrado biome, Eugenia dysenterica (Zucchi et al. 2003). The study evaluated the genetic diversity with the use of seven microsatellite loci developed for Eucalyptus sp. In the study, estimations of gene diversity were superior $(0.458)$ to what was obtained in the present enquiry, although the average number of alleles per locus (3.12) was similar. Collevatti et al. (2001b) studied 10 populations of Caryocar brasiliense using microsatellite markers developed for the species and obtained an average of 10.6 alleles per locus. It is believed that the low polymorphism of nuclear microsatellite loci in Solanum lycocarpum is due to these primers having been developed in another genus (Capsicum).

Comparative studies between homologue microsatellite loci in different species have shown that both polymorphism and the allele size tend to be higher for species in which the loci were characterized for the first time (focal species) (Jarne and Lagoda 1996). Though there is no consensus for the explanation of these trends, some hypotheses have been raised.
Firstly, one explanation concerns the phylogenetic distance between species. The success in the heterologous amplification is usually inversely proportional to the time of phylogenetic separation of both species. The cumulative effect of mutations on the flanking regions of microsatellites in the non-focal species may cause either the failure of heterologous amplification or the absence of polymorphism - in the latter case; it is due to the fixation of null alleles (Chambers and MacAvoy 2000).

Secondly, another explanation is related to the non-randomization of the loci selection for the focal species. During the characterization of the loci, those with the biggest alleles and the highest polymorphism are supposed to be collected, and this demonstrates that the sampling effort in detecting polymorphism is biggest in the focal species (Chambers and MacAvoy 2000). Based on these evidences, the conclusions regarding gene diversity in studied populations with microsatellite loci developed for other species must be taken with caution, as in the comparison between species.

The fixation index $(\hat{f})$ measures the rate of heterozygous genotypes as compared to what is expected by the Hardy-Weinberg Equilibrium. High estimations of fixation indices are usually regarded as a result of inbreeding in the population. The occurrence of point mutations in the loci primer sequences has been determined as the main cause of the erroneous detection of a large amount of homozygous genotypes (Aldrich et al. 1998; White et al. 1999). One mutation in the locus primer sequence results in failure in the amplification of one of the alleles, called a null allele. 
Null alleles have been found in over $25 \%$ of microsatellite loci, reaching frequencies of over 15\% (Jarne and Lagorda 1996). The study of the mating system of $S$. lycocarpum has proved that the species mates preferably by outcrossing, and that selfings and biparental inbreeding do not usually occur. Although null alleles have not been detected in the data set, the higher $\hat{f}$ value was observed in population $\mathrm{A}$, where two loci showed heterozygosity deficiency. As a highly significant shortage of heterozygote genotypes with alleles of one repeat unit difference was observed, it is possible to deduce that scoring errors due to stuttering contributed more than inbreeding to the estimation of high $\hat{f}$ value in population A.

Although the fixation index was low in populations $\mathrm{B}, \mathrm{C}$ and $\mathrm{D}$, all presented spatial structure of genotypes. Pairwise $\hat{F}_{i j}$ estimates tended to decrease linearly with the logarithm of the pairwise spatial distances, as predicted by the isolation by distance theory. The spatial structure of genotypes has been associated with the spatially restricted dispersion of seeds, in which the fruits fall and the seeds germinate near the mother-tree (GonzálezMartínez et al. 2002). It is believed that the spatially restricted dispersion as well as vegetative reproduction may have contributed to the spatial structure in S. lycocarpum.

As the number of nuclear SSR alleles was small, confident detection of clones was not possible. The vegetative reproduction per root in $S$. lycocarpum was not assessed in the present enquiry, and no other studies on the subject were found. Nevertheless, it is known that regeneration after a shallow cut to the trunk is frequent (personal observation). As about $30 \%$ of the plant mass in the Cerrado biome is radicular (Rizzini and Heringer 1962), it is common that a plant with a small aerial part may possess a developed root system. Small-sized $S$. lycocarpum individuals (about $30 \mathrm{~cm}$ tall) with flowers and fruit are often found in anthropogenic Cerrado vegetation environments (personal observation), hinting that these could have resulted from root regeneration.

The fruit features and the behavior of the main seed dispersing agents may also have contributed to spatial genetic structure. Fallen fruits that are not consumed by fruit-eating animals are commonly noticed. Their seeds may germinate under the crown of the mother-tree in such a way that the spatially nearest individuals in the population are siblings of the same mother. Sauba ants have an important role in the secondary dispersion of the seeds: they carry the seeds from fallen fruits as well as from animal excrements to their nests. The distance of the migration, however, is about only $3.4 \mathrm{~m}$ (Pinto 1998), and about $40 \%$ of the seeds taken to nests are discarded (Courtenay 1994). S. lycocarpum plants are very commonly found on sauba ant' nests, not only because of the saubas' behavior but also because maned wolfs prefer to defecate in high places, such as on raised nests and termitaries. In addition, cattle usually eat $S$. lycocarpum fruits and disperse its seeds. As the transit of animals is restricted to the pasture area, the cattle disperse seeds only within that population and may, therefore, be contributing to the occurrence of genotype spatial structure and coancestry. Cattle transit was verified in population B and D.

Another factor that may be contributing to the spatial genetic structure is the behavior of the main pollinating agent (Xylocopa sp.). In the vibratile pollination the vibration of the bee raises a cloud of pollen, and the bee visits all the neighboring open flowers before flying to further plants. This behavior could be favoring outcrossings between spatially near individuals. On the other hand, the analysis of the species' mating system evidenced that both the outcrossing rate and the number of pollen donors in the outcrossings are high. Pollen grain germination experiments showed that the successful production of fruits was only verified for hermaphrodite flowers and after cross-pollination (Oliveira-Filho and Oliveira 1988). The authors' considerations corroborate the results obtained in this study, namely the high outcrossing rates. The spatial genetic structure in three $S$. lycocarpum populations (average $\mathrm{Sp}=0.184 \pm 0.003$ ) was similar to that observed for outcrossing $(\mathrm{Sp}=0.0126 \pm 0.0101)$ and self-incompatible $(\mathrm{Sp}=0.0134 \pm 0.0077)$ species (Vekemans and Hardy 2004).

The species' floral feature is a factor that may have contributed to the large number of pollen donors in the outcrossings. S. lycocarpum is an andromonoecious species and the main consequence of the andromonoecy is the higher occurrence of pollen/ovule. Both types of flowers, which stay open for $24 \mathrm{~h}$, produce a high amount of viable pollen (Oliveira-Filho and Oliveira 1988). Despite few flowers being open at the same time in each individual, many flowers open daily in the total popu- 
lation. Even when pollen dispersion seems to be highly localized, the actual gene flow (resulting from viable seeds) may be occurring at bigger distances (Slatkin 1985). Theoretical studies and simulations (Wright 1943; Epperson 1990; Epperson 1995) have demonstrated that under restricted gene flow conditions, populations develop a spatial genotype structuring. Even so, with a positive correlation that declines with distance, spatial auto-correlation in natural populations is weak and/or inconsistent (Heywood 1991; Smouse and Peakall 1999). However, adjacent individuals in population $\mathrm{D}$ evidenced a higher kinship coefficient $\left(\hat{F}_{(1)}=0.1152\right)$ than estimations of populations A, B and C $\left(\hat{F}_{(1)}=-0.0351,0.0365\right.$ and 0.0498 , respectively). Many hypotheses may be raised to explain the differential pattern of population $\mathrm{D}$ as compared to the other populations studied.

Firstly, it may be inferred that population D has a more recent origin than the other populations. The individuals of $S$. lycocarpum could have been settled for just a few generations, or they might have suffered a bottleneck. In the latter case, as there are few overlapped generations, the coancestry is higher. This hypothesis is corroborated by the occurrence of a bigger rate of linkage disequilibria loci in this population (data not presented), as well as by the lower genetic diversity in the chloroplast and nuclear loci.

Secondly, two factors that operated together may have contributed to the coancestry: the number of individuals that belong to the same generation and the restriction of gene flow by seeds in population D. Probably, the transit of fruit-consumer fauna is less frequent, resulting both in the smaller colonization by seeds brought from other areas and in spatial restriction of the dispersion of the seeds produced in the population. In contrast to other populations, population D showed a larger quantity of fallen ripe fruit uneaten on the ground, indicating a smaller frequency of dispersing agents. In this case, there are many groupings of observed individuals in the population that are mother and offspring or siblings of the same mother. This hypothesis is corroborated by the spatial genetic structure and by the field observation that there are many groupings of $S$. lycocarpum formed by a large reproductive plant with several smaller ones around it.

Thirdly, the difference in reproductive success among mothers may have occurred concomitantly to the factors already mentioned. A small number of mothers contributed (and continues contributing) with a big number of descendents in the population. The smaller number of chloroplast haplotypes observed in the studied population corroborates this hypothesis.

Solanum lycocarpum is a species with a wide potential for being planted in restoration plans. For the studied populations, in the field collection of seeds to produce seedlings, the same number of seeds from 150 to 200 mother trees must be collected, so that the effective number of 500 individuals can be kept the same. As the species is spread all over the Cerrado biome, the collection must be planned so as to sample the biggest possible number of populations in an extensive area. This will enable the retention of the maximum possible haplotypic diversity.

\section{Acknowledgements}

We specially thank Prof. Márcio Elias Ferreira (EMBRAPA Genetic Research and Biotechnology) by providing nSSR primer sequences and Prof. Roland Venconvsky (ESALQ-USP) by assistance in statistical analysis. We also thank the staff of the Laboratório de Reprodução e Genética de Espécies Arbóreas (LARGEA-ESALQ/USP), especially Elza Ferraz, Andréia Moreno and Gabriela Defávari for the continued support in the laboratory. This work was supported by Fundação de Amparo à Pesquisa do Estado de São Paulo (FAPESP/ Brazil). K. Martins has received a Ph.D. fellowship from Conselho Nacional de Desenvolvimento Científico e Tecnológico (CNPq/Brazil).

\section{References}

Aldrich PR, Hamrick JL, Chavarriage P, Kochert G (1998) Microsatellite analysis of demographic genetic structure in fragmented populations of the tropical tree Symphonia globulifera. Mol. Ecol., 7, 933-944.

Buchmann SL (1983) Buzz pollination in Angiosperms In: Handbook of Experimental Pollination Biology (eds. Jones CE, Little RJ), pp. 73-113. Van Nostrand \& Reinhold Scientific and Academic Editions, New York.

Buso GSC, Brondani RV, Amaral ZP de S, Reis AMM, Ferreira ME (2000) Desenvolvimento de primers SSR para análise genética de pimentas e pimentões (Capsicum spp.) utilizando biblioteca genômica enriquecida, Boletim de Pesquisa $n^{\circ} 15$, Embrapa/Cenargen, Brasília. 
Chambers GK, MacAvoy ES (2000) Microsatellites: consensus and controversy. Comp. Biochem. Physiol. B, 126, 455-476.

Chaves-Filho JT, Stacciarini-Seraphin E (2001) Alteração do potencial osmótico e do teor de carboidratos solúveis em plantas jovens de lobeira (Solanum lycocarpum St.Hil) em resposta ao estresse hídrico. Rev. Bras. Bot., 24, 199-204.

Cockerham CC (1969) Variance of gene frequencies. Evolution, 23, 72-84.

Collevatti RG, Grattapaglia D, Hay JD (2001a) High resolution microsatellite based analysis of the mating system allows the detection of biparental inbreeding in Caryocar brasiliense, an endangered tropical tree species. Heredity, 86, 6067.

Collevatti RG, Grattapaglia D, Hay JD (2001b) Population genetic structure of the endangered tropical tree species Caryocar brasiliense, based on variability at microsatellite loci. Mol. Ecol., 10, 349-356.

Collevatti RG, Grattapaglia D, Hay JD (2003) Evidences for multiple maternal lineages of Caryocar brasiliense populations in the Brazilian Cerrado based on the analysis of chloroplast DNA sequences and microsatellite haplotype variation. Mol. Ecol., 12, 105-115.

Courtenay O (1994) Conservation of the maned wolf: fruitful relations in a changing environment. Canid News, 2, 41-43.

Creste C, Tulmann Neto A, Figueira A (2001) Detection of single sequence repeat polymorphisms in denaturing polyacrylamide sequencing gels by silver staining. Plant Mol. Biol. Rep., 19, 299-306.

Cruz GL (1982) Dicionário das plantas úteis do Brasil, 2nd edn. Civilização Brasileira, Rio de Janeiro.

Dall'Agnol R, Von Poser GL (2000) The use of complex polysaccharides in the management of metabolic diseases: the case of Solanum lycocarpum fruits. J. Ethnopharmacol., 71, 337-341.

Doyle JJ, Doyle JS (1990) Isolation of plant DNA from fresh tissue. Focus, 12, 13-15.

Elias SM, Assis RM, Stacciarini-Seraphin E, Rezende MH (2003) Anatomia foliar em plantas jovens de Solanum lycocarpum St.Hil. (Solanaeceae). Rev. Bras. Bot., 26, 169-174.

Epperson BK (1990) Spatial patterns of genetic variation within plant populations In: Plant Population Genetics, Breeding, and Genetic Resources (eds. Brown AHD, Clegg MT, Kahler AL, Weir BS), pp. 229-253. Sinauer Associates, Sunderland.

Epperson BK (1995) Spatial distributions of genotypes under isolation by distance. Genetics, 140, 1431-1440.

González-Martínez SC, Gerber S, Cervera MT, Martínez-Zapater JM, Gil L, Alía R (2002) Seed gene flow and fine-scale structure in a Mediterranean pine (Pinus pinaster Ait.) using nuclear microsatellite markers. Theor. Appl. Genet., 104, 1290-1297.

Hall P, Walker S, Bawa K (1996) Effect of forest fragmentation on genetic diversity and mating system in a tropical tree, Pithecellobium elegans. Conserv. Biol., 10, 757-768.

Hardy OJ, Vekemans X (2002) SPAGeDi: a versatile computer program to analyse spatial genetic structure at the individual or population levels. Mol. Ecol. Notes, 2, 618-620.

Hardy OJ, Vekemans X (1999) Isolation by distance in a continuous population: reconciliation between spatial autocorrelation and population genetic models. Heredity, 83, 145-154.
Heywood JS (1991) Spatial analysis of genetic variation in plant populations. Annu. Rev. Ecol. Syst., 22, 335-355.

Hoffmann WA (1998) Post-burn reproduction of woody plants in a neotropical savanna: the relative importance of sexual and vegetative reproduction. J. Appl. Ecol., 35, 422-433.

Howe HF, Smallwood J (1982) Ecology of seed dispersal. Annu. Rev. Ecol. Syst., 13, 201-228.

Jarne P, Lagoda PJL (1996) Microsatellites, from molecules to populations and back. Trends Ecol. Evol., 11, 424-429.

Lacerda DR, Acedo MDP, Lemos Filho JP, Lovato MB (2001) Genetic diversity and structure of natural populations of Plathymenia reticulata (Mimosoideae), a tropical tree from the Brazilian Cerrado. Mol. Ecol., 10, 1143-1152.

Levin DA (1981) Dispersal versus gene flow in plants. Ann. Missouri Bot. Gard., 68, 233-253.

Lewis PO, Zaykin D (2001) Genetic Data Analysis: Computer program for the analysis of allele data. Version $1.0(\mathrm{~d} 16 \mathrm{c})$. Free program distributed by the authors over the internet from http://www.lewis.eeb.uconn.edu/lewishome/software.html.

Loiselle BA, Sork VL, Nason J, Graham C (1995) Spatial genetic structure of a tropical understorey shrub, Psychotria officinalis (Rubiaceae). Am. J. Bot., 82, 1420-1425.

Lombardi JA, Motta-Junior JC (1993) Seed dispersal of Solanum lycocarpum St. Hil. (Solanaceae) by the maned wolf, Chrysocyon brachyurus Illiger (Mammalia, Canidae). Ciência e Cultura, 45, 126-127.

Lorenzi H (1998) Árvores Brasileiras: Manual de Identificação e Cultivo de Plantas Arbóreas Nativas do Brasil, Plantarum, Nova Odessa.

Lorenzi H (2000) Plantas daninhas do Brasil: terrestres, aquáticas, parasitas e tóxicas, 3rd edn. Plantarum, Nova Odessa.

Loveless MD, Hamrick JL (1984) Ecological determinants of genetic structure in plant populations. Annu. Rev. Ecol. Syst., 15, 65-95.

McCauley DE (1995) The use of chloroplast DNA polymorphism in studies of gene flow in plants. Trends Ecol. Evol., 10, 198-202.

Motta-Junior JC, Martins K (2002) The Frugivorous diet of the maned wolf, Chrysocyon brachyurus in Brazil: ecology and conservation. In: Seed Dispersal and Frugivory: Ecology, Evolution and Conservation (eds. Levey DJ, Silva WR, Galetti M), pp. 291-303. CABI Publishing, Wallingford.

Motta-Junior JC, Talamoni AS, Lombardi JA, Simokomaki K (1996) Diet of maned wolf, Chrysocyon brachyurus, in central Brazil. J. Zool., 240, 277-284.

Oliveira-Filho AT, Oliveira LCA (1988) Biologia floral de uma população de Solanum lycocarpum St Hil (Solanaceae) em Lavras, MG. Rev. Bras. Bot., 11, 23-32.

Oosterhout CV, Hutchinson WF, Wills DPM, Shipley P (2004) Micro-checker: software for identifying and correcting genotyping errors in microsatellite data. Mol. Ecol. Notes, $\mathbf{4}$, 535-538.

Pijl LV (1972) Principles of Dispersal in Higher Plants, 2nd edn. Springer Verlag, New York.

Pinto FS (1998) Efeitos da dispersão de sementes por animais e dos fatores edáficos sobre a germinação, crescimento e sobrevivência das plântulas de lobeira, Solanum lycocarpum. Master Thesis, Universidade de Brasília, Brasília, Brazil.

Ritland K (1989) Correlated matings in the partial selfer Mimulus guttatus. Evolution, 43, 848-859. 
Ritland K (2002) Extensions of models for the estimation of mating systems using $n$ independent loci. Heredity, 88, 221228 .

Ritland K, Jain S (1981) A model for the estimation of outcrossing rate and gene frequency using $n$ independent loci. Heredity, 47, 35-52.

Rizzini CT, Heringer EP (1962) Studies on the underground organs of trees and shrubs from some southern Brazilian savannas. An. Acad. Bras. Cien., 34, 235-247.

Rodrigues FHG (2002) Biologia e conservação do lobo-guará na Estação Ecológica de Águas Emendadas, DF. Master Thesis, Universidade Estadual de Campinas, Campinas, Brazil.

Rousset F (1997) Genetic differentiation and estimation of gene flow from $F$-statistic under isolation by distance. Genetics, 145, 1219-1228.

Sebbenn AM (2003) Tamanho efetivo para conservação ex situ de espécies arbóreas com sistema misto de reprodução. Rev. Inst. Flor. Sao Paulo, 15, 147-162.

Slatkin M (1985) Gene flow in natural populations. Аnпи. Rev. Ecol. Syst., 16, 393-430.

Smouse PE, Peakall R (1999) Spatial autocorrelation analysis of individual multiallele and multilocus genetic structure. Heredity, 82, 561-573.

Stenberg P, Lundmark M, Saura A (2003) MLGSim: a program for detecting clones using a simulation approach. Mol. Ecol. Notes, 3, 329-331.
Telles MPC, Diniz-Filho JAF, Coelho ASG, Chaves LJ (2001a) Autocorrelação especial das freqüências alélicas em subpopulações de cagaiteira (Eugenia dysenterica DC., Myrtaceae) no sudeste de Goiás. Rev. Bras. Bot., 24, 145-154.

Telles MPC, Silva RSM, Chaves LJ, Coelho ASG, Diniz-Filho JAF (2001b) Divergência entre subpopulações de cagaiteira (Eugenia dysenterica) em resposta a padrões edáficos e distribuição espacial. Pesqui. Agropec. Bras., 36, 1387-1394.

Telles MPC, Valva FD, Bandeira LF, Coelho ASG (2003) Caracterizaç ão genética de populações naturais de araticunzeiro (Annona crassiflora Mart. - Annonaceae) no Estado de Goiás. Rev. Bras. Bot., 16, 123-129.

Vekemans X, Hardy OJ (2004) New insights from fine-scale spatial genetic structure analyses in plant populations. Mol. Ecol., 13, 921-935.

Weising K, Gardner RC (1999) A set of conserved PCR primers for the analysis of simple sequence repeat polymorphisms in chloroplast genome of dicotyledonous angiosperms. Genome, 42, 9-19.

White GM, Boshier DH, Powell W (1999) Genetic variation within a fragmented population of Swietenia humilis Zucc. Mol. Ecol., 8, 1899-1909.

Wright S (1943) Isolation by distance. Genetics, 28, 139-156.

Zucchi MI, Brondani RPV, Pinheiro JB, Chaves LJ, Coelho ASG, Vencovsky R (2003) Genetic structure and gene flow in Eugenia dysenterica DC in the Brazilian Cerrado utilizing SSR markers. Genet. Mol. Biol., 26, 449-457. 